\title{
Innovation for Making Potable Water Available in Saline Groundwater Areas
}

\author{
Lalit Mohan Sharma \\ S M Sehgal Foundation, Gurgaon, India \\ Email: lalit.sharma@smsfoundation.org, lalit.water@gmail.com
}

Received 14 August 2014; revised 12 September 2014; accepted 4 October 2014

Copyright (C) 2014 by author and Scientific Research Publishing Inc.

This work is licensed under the Creative Commons Attribution International License (CC BY). http://creativecommons.org/licenses/by/4.0/

(c) (i) Open Access

\begin{abstract}
Groundwater salinity is a widespread problem around the world with adverse consequences on health, soil quality and overall eco-systems. With the rapidly growing demands of groundwater, its exploitation is also accelerating. It is also changing the flow of the groundwater, which in turn causes ingress of sea water or intrusion of other saline groundwater or polluted water from the surrounding areas. The major consequences are scarcity of water even for domestic use and rise in the level and spread of groundwater salinity. An innovative technique of creating a pool of fresh groundwater within a saline aquifer is developed, which can address the issue. Technique is about recharging the saline aquifer with harvested rain water in such a way that recharged rain water does not get mixed with the existing saline groundwater rather it forms pool of fresh water in the saline aquifer. Water from this pool can be extracted without getting it mixed with saline groundwater. This innovation also eliminates the need of cost intensive provision of water storage structures to store rain water for fulfilling the domestic water needs. Thus, the saline aquifer unsuitable or otherwise useless for groundwater development can be used.
\end{abstract}

\section{Keywords}

Rain Water Harvesting, Hydro-Static Pressure, Saline Groundwater, Pool of Fresh Water

\section{Introduction}

Groundwater is an essential component of water resource system. Being the largest reserve of drinkable water for human population, groundwater has always been of great importance to human civilization. In India, 85\% of drinking water supplies and $60 \%$ of irrigated agriculture are Groundwater dependent [1].

Semiarid regions are most vulnerable to the adverse effects of groundwater salinity. Here, surface water resources are scarce and highly unreliable due to low rainfall $(200-500 \mathrm{~mm})$ and extended summer season. As a 
result, groundwater tends to be the primary source of water. Ever increasing demand on decreasing water availability leads to fast depletion of aquifers. It is often observed that groundwater salinity increases with depth. Thus, fast depletion of the groundwater further increases salinity.

Further, the quality of groundwater has become an increasing concern due to increasing contamination by various toxic substances [2]. One of the major aspects in the deterioration of water quality is an increase in overall salinity. Saline water has a relatively high concentration of dissolved salts (cations and anions). Healthrelated studies have shown that intake of toxic compounds through water may result in water borne diseases. In India, water borne diseases annually put a burden of 3.1 - 8.3 million USD on the economy [3].

When groundwater mining is more than the recharge, depletion is caused. This may further change groundwater flow direction which in turn causes ingress of sea water or intrusion of other saline ground/surface water or polluted water from the surrounding areas, affecting the quality of groundwater itself. In the absence of any regulatory policy for groundwater mining, the situation gets exacerbated.

Presence of fluoride, nitrate, iron, arsenic, total hardness and few toxic metal ions determine salinity levels in groundwater. According to International Groundwater Resource Assessment Centre inventory, the total area with high groundwater salinity at shallow or intermediate depth approximates 24 million square $\mathrm{km}$. It is about $16 \%$ of the total land area on earth. The Basins of West and Central Asia has the largest area with high groundwater salinity. It contributes to $14 \%$ of the total groundwater salinity area [4].

In India, saline groundwater is found in many states particularly in the arid and semi-arid regions of Rajasthan, Haryana, Punjab and Gujarat and to a lesser extent in Uttar Pradesh, Delhi, Madhya Pradesh Maharashtra, Karnataka, Bihar and Tamil Nadu. In India, about 200,000 sq.km area has been estimated to be affected by saline water [5].

Table 1 presents the districts affected by salinity and fluoride in groundwater in Haryana. High salinity is affecting groundwater quality in more than $30 \%$ of areas of districts Gurgaon, Bhiwani, Rohtak, Mahindergarh and Sonepat.

However of these districts, the recently formed district of Mewat is a case in point as far as groundwater salinity and fluoride are concerned. Mewat suffers from acute water scarcity, and lacks good quality of water as it is underlain with saline groundwater aquifers. The problem worsens for the inhabitants as groundwater is the primary source of water for this water scarce region. Fresh groundwater is available only in few pockets under the ground. Only $22 \%$ of the district area has fresh groundwater whereas $78 \%$ has saline [7]. As reported in 2004, out of 503 villages of Mewat only 61 villages have fresh groundwater the rest have saline groundwater [8]. Lack of fresh water has far reaching consequences that have a bearing on district's economy, socio-political set-up and health status of its inhabitants.

Shallow water table coupled with high salinity has impacted the socio-economic conditions. With more than three-fourth of working population engaged in agriculture-related activities, people have to depend on saline groundwater. It adversely affects productivity by deteriorating soil quality and limits the choices of crops for farmers [9].

Women and young girls have to travel (3 - 4 kilometres spending minimum an hour each trip) to fetch water. On an average, a household that can't afford buying water from tankers have to make five such trips to collect water to meet daily domestic requirements. As a result, many young girls are unable to attend school. Further, they are also prone to many health-related problems caused due to carrying water load.

In this paper, we discuss an innovative approach that can ensure sustainable potable water source to fulfill the domestic needs of the inhabitants in saline groundwater villages. This will also offer an economical and longterm solution, taking into account the social, economic and environmental conditions.

\section{Innovative Solution to Provide Potable Water}

An innovative model was conceived based on a thorough understanding of the local conditions and constraints

Table 1. Salinity and fluoride-affected districts in Haryana.

\begin{tabular}{cc}
\hline Contaminants & Districts affected in parts \\
\hline Salinity & Sonepat, Rohtak, Hissar, Sirsa, Faridabad*, Jind, Gurgaon ${ }^{*}$, Bhiwani, Mahendragarh \\
Fluoride & Rohtak, Jind, Hissar, Bhiwani, Mahendragarh, Faridabad \\
\hline
\end{tabular}

Source: Central Groundwater Board [6]. "Mewat was carved out of Faridabad and Gurgaon. 
in the rural Mewat, including:

- Non-availability of reliable grid electrical supply.

- Limited purchase power.

- Very short rainy season with annual average rainfall of $594 \mathrm{~mm}, 31$ rainy days.

- Shallow groundwater table.

- High levels of groundwater salinity.

- Low skill-set of locals.

In above constraints, rain water harvesting was considered the best option to create fresh water resource locally. Based on opportunities and constraints in the region, RWH seemed the most suitable option. In many rural parts of India with similar water conditions, particularly Rajasthan and Gujarat, RWH is considered as the best traditional practice to solve water scarcity. In this, harvested water is stored in underground tanks called Tankas. The design and storage capacity of these tanks is determined by water demands and average rainfall in the region.

Another popular traditional option for storing water under ground is Kund or Kundi, practiced in Churu district of Rajasthan. These Kunds or underground pits/tanks are roughly 6 meters deep and 2 meters broad, resting over semi-permeable to non-permeable soil strata to store harvested rain water. The stored water remains intact in kunds as it is not exposed to light and air. Also, it does not percolate down because of low permeability of the strata, which is further plugged by fine silt coming with water. However, the geological conditions of Mewat don't permit the adoption of Kund in the region, as the soil here is sandy and groundwater is very shallow in saline groundwater areas.

Another option available was to recharging the groundwater with harvested rain water. Usually, recharging is done at a depth under the ground, leaving safe distance above the groundwater table, so that the recharged water gets infiltrated into the ground in order to avoid chances of contamination of groundwater. But this recharged fresh water does not remain in a consolidated mass but spreads out over a period of time to ultimately produce a thin layer of fresh groundwater over the existing saline groundwater to maintain the hydraulic equilibrium, as shown in Figure 1.

Exploiting this thin layer of fresh groundwater separately is practically very difficult as it gets mixed up with the existing underlain saline groundwater in the process. In order to exploit the harvested rain water separately, it should form a sizeable pool or pocket instead of thin layer spread over larger area. To achieve this, an innovative change in the traditional recharging methods was adopted. In the new innovative model, recharge wells are sunk to a depth, lower than groundwater table. With it, desired fresh water pocket could be easily formed by pushing away and replacing the existing saline groundwater. When groundwater is extracted from recharge well, the harvested fresh water from this pocket could be reached, as it is pushed by surrounding saline groundwater pressure.

Another challenge limiting the quantity of recharge is the shallow depth of groundwater table. Particularly in saline groundwater areas of Mewat depth of groundwater table varies from four feet to ten feet. The shallow

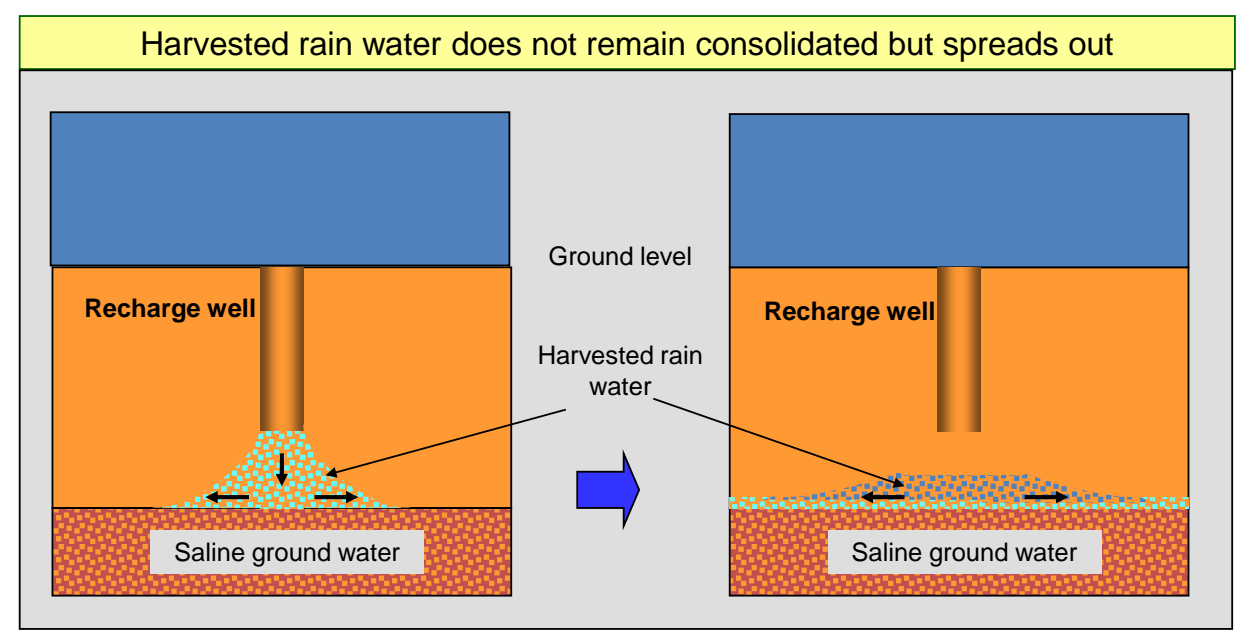

Figure 1. Spread of fresh harvested rain water under the ground. 
groundwater depth creates low hydrostatic pressure (over burden pressure) for recharging resulting low rate of recharging. This limits the quantity of recharge. To overcome this challenge, recharge well is raised to roof height, leaving a margin to accommodate a pre-filter to remove suspended and floating materials coming with rain water from the roof. This way, the hydro-static pressure for recharging is increased by head of about three meters.

\section{Underlying Concept}

The rain water harvested from the roof is directed under the ground through recharge wells continued below the groundwater table to form a pocket of fresh water. The scientific explanation of formation of fresh groundwater pocket within saline one is as follows:

- Because of overburden/hydro-static pressure harvested fresh water pushes away the existing saline groundwater and takes its place to forms a pocket of itself within the saline aquifer.

- The streamline flow of fresh water under the ground (through the tiny void spaces among the soil particles) causes minimal turbulence, negating any stirring effect. It prevents diffusion/mixing of harvested and existing saline water.

- The first rush of water into the void spaces flushes out chemical residues of saline groundwater, limiting chemical contamination to the boundary of fresh water pocket.

- The buoyant force exerted by surrounding saline groundwater on the newly formed pocket of harvested water keeps the harvested water pocket intact from scattering.

- The process of diffusion through Brownian Motion (BM) (BM is the random movement of particles suspended in liquid or gaseous state, leading to diffusion. Diffusion is a net transport of molecules from a region of higher concentration to one with lower concentration by random molecular motion. The result of diffusion is a gradual mixing of material) is curtailed because of limited free space available within soil voids.

- Water stored under ground remains totally cut off from sunlight and air, preventing growth of pathogens and minimizing the chances of further biological contamination.

The model is cost effective as it does not require any additional cost to create a storage structure. However, in the shallow water table areas, there could be a potential risk of biological contamination. In order to address this, bio-sand filter is suggested as an economical and sustainable solution.

\section{RWH Model in Untka School}

The school catering to 297 students had no local source of water. Its daily requirement of water for drinking and mid day meal cooking is 750 liters (297@2.5 liters/day) and total annual water demand works out to be 150,000 liters, for 200 working days per year. Here groundwater is highly saline having total dissolved solids (TDS) as $5980 \mathrm{mg} / \mathrm{l}$.

In 2013, roof water harvesting (RWH) system was established to recharge aquifer with rain water catering to following objectives:

- To create local source of potable water by creating fresh water pocket within saline aquifer.

- To generate the awareness among schoolchildren about RWH, so that they could further impart awareness in the community.

- To demonstrate the feasibility of the model and acquire a buy-in from the community for replication.

With the financial support from Department of Science and Technology (Government of India), the RWH unit was set up for a roof area of 638 square meters to capture rain water. The average annual rainfall of $594 \mathrm{~mm}$ can result in estimated annual harvest of 322,126 liters of water, considering the run-off factor as 0.85 . Since July 2013, the school is using the recharged water filtered through bio-sand filter to eliminate the risk of biological contamination. The present water harvesting capacity surpasses the required amount, resulting in sustainable and reliable water supply for the school. Figure 2 shows the scheme of the model and actual picture of site.

\section{Results}

The school with highly saline groundwater (TDS-5980 mg/l) has a ready and reliable source of potable water, which was further purified using bio-sand filter to eliminate the chances biological contamination. TDS of water pumped out of the pool of fresh water created in the saline aquifer is monitored on monthly basis. The observations are given in Table 2. 


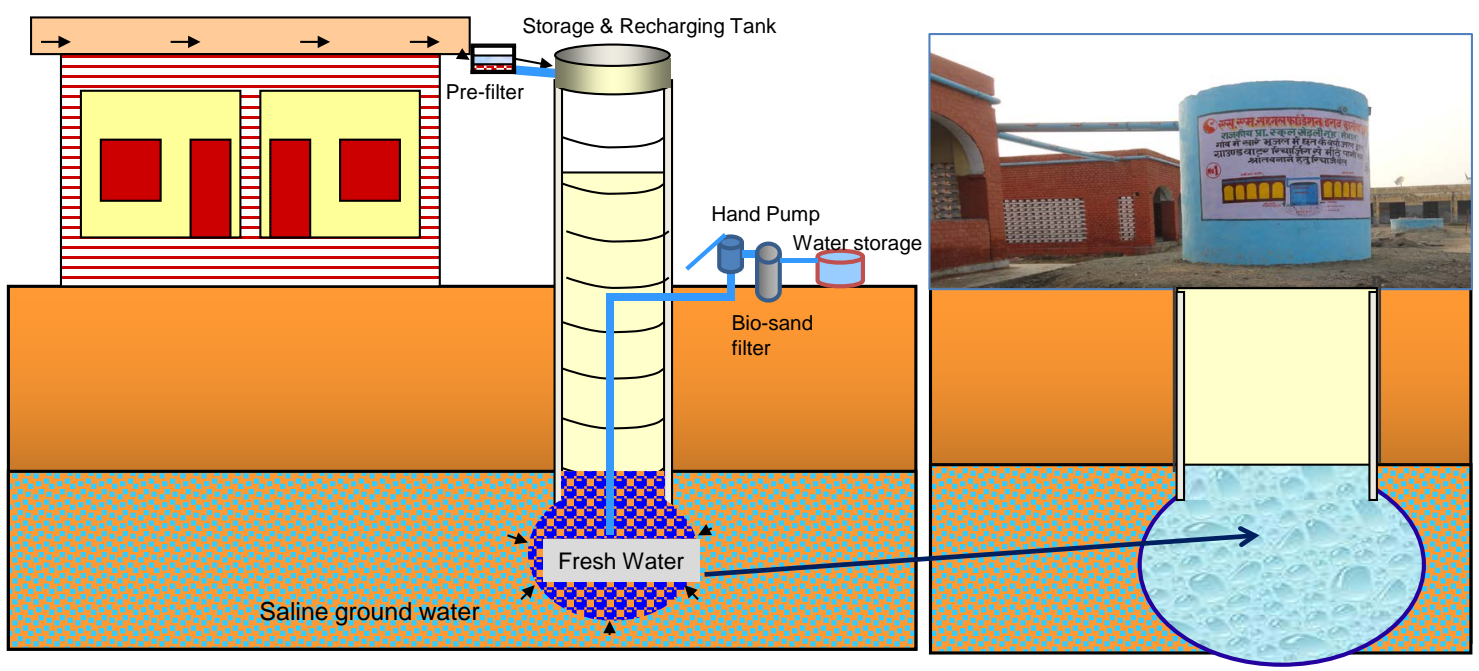

Figure 2. Schematic diagram of model with actual picture.

Table 2. Total dissolved solids of created pool of fresh water.

\begin{tabular}{cccccccccccc}
\hline & \multicolumn{4}{c}{ Year 2013} \\
\hline Month & Aug. & Sep. & Oct. & Nov. & Dec. & Jan. & Feb. & Mar. & Apr. & May & Jun. \\
TDS (mg/l) & 91 & 92 & 88 & 92 & 95 & 82 & 99 & 96 & 102 & 108 & 98 \\
\hline
\end{tabular}

Table 2 depicts the salinity level of water pumped from the pool of fresh water created in the saline aquifer monitored on monthly basis. The salinity level is much below $500 \mathrm{mg} / \mathrm{l}$ the permissible level round the year. However these levels are minimum during October and January due to rains in this period. The freshly harvested rain water diluted the salinity level further.

\section{Conclusion}

This model is a sustainable solution for creating potable water availability in the saline ground water areas. The model has high scaling potential in regions with saline ground water and coastal areas where sea water ingress poses a major challenge of groundwater salinity. Experiences from Untka School and other five more locations hint that replication of the model is highly affordable and can be easily done. Though this model is conceptualized and developed in shallow aquifer areas but the model can also be adapted for deeper saline aquifers with minor changes in the design.

\section{Acknowledgements}

I thank Dr. Suri Sehgal and Jay Sehgal for encouraging and motivating me during development of this innovation; thanks are also due to "Water Technology Initiative (Department of Science and Technology, Government of India)” for financial support to implement demonstrations in villages; Mr. Salahuddin Saiphy, Mr. Mahipal Singh and Mr. Saddique for support in implementation and the entire S M Sehgal Foundation Team for their support in the overall process.

\section{References}

[1] Garduno, H., Romani, S., Sengupta, B., Tuinhof, A. and Davis, R. (2014) India Groundwater Governance Case Study. http://water.worldbank.org/sites/water.worldbank.org/files/GWGovernanceIndia.pdf

[2] Tariq, R.S., Shah, M.H., Shaheen, N., Jaffar, M. and Khalique, A. (2008) Statistical Source Identification of Metals in Groundwater Exposed to Industrial Contamination. Environmental Monitoring and Assessment, 138, 159-165. http://dx.doi.org/10.1007/s10661-007-9753-8

[3] Mukherjee, S. (2008) Factors Influencing Farmers’ Willingness to Protect Groundwater from Non-Point Sources of 
Pollution in the Lower Bhavani River Basin, Tamil Nadu, India. 3rd Water Environment Partnership in Asia (WEPA) International Forum on Water Environmental Governance in Asia.

[4] International Groundwater Resource Assessment Centre (IGRAC) (2014) Saline Groundwater: Global Map. http://www.un-igrac.org/publications/344

[5] Central Groundwater Board (CGWB) (2014) Groundwater Quality Features of the Country. http://cgwb.gov.in/documents/GROUND\%20WATER\%20QUALITY\%20SCENARIO\%20IN\%20INDIA.pdf

[6] Central Groundwater Board (CGWB) (2014) State Profile: Groundwater Scenario. http://www.cgwb.gov.in/gw_profiles/St_Haryana.htm

[7] Central Groundwater Board (CGWB) (2008) District Profile: Mewat. www.cgwb.gov.in/district profile/haryana/mewat.pdf

[8] SANDRP (2004) Dams Rivers and People. SANDRP, 2, 32.

[9] Tanwar, B.S. and Kruseman, G.P. (1985) Saline Ground Water Management in Haryana State, India. Hydrogeology in the Service of Man. Mémoires of the 18th Congress of the International Association of Hydrogeologists, Cambridge, 24-30. 
Scientific Research Publishing (SCIRP) is one of the largest Open Access journal publishers. It is currently publishing more than 200 open access, online, peer-reviewed journals covering a wide range of academic disciplines. SCIRP serves the worldwide academic communities and contributes to the progress and application of science with its publication.

Other selected journals from SCIRP are listed as below. Submit your manuscript to us via either submit@scirp.org or Online Submission Portal.
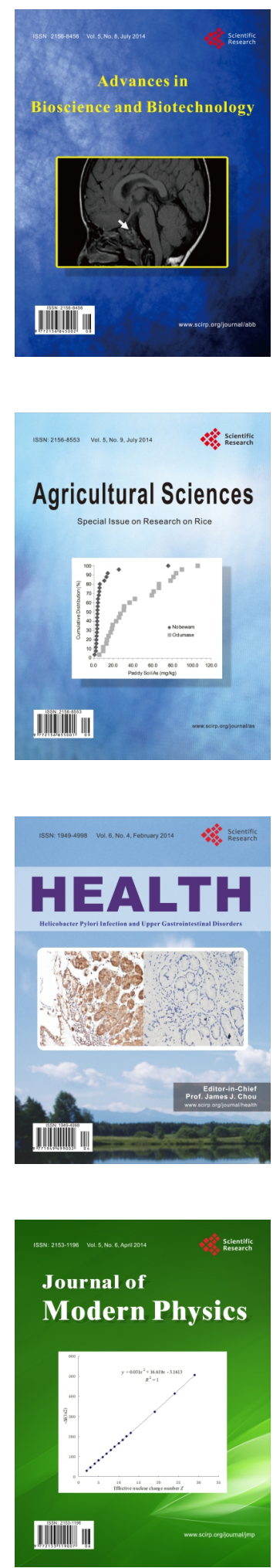
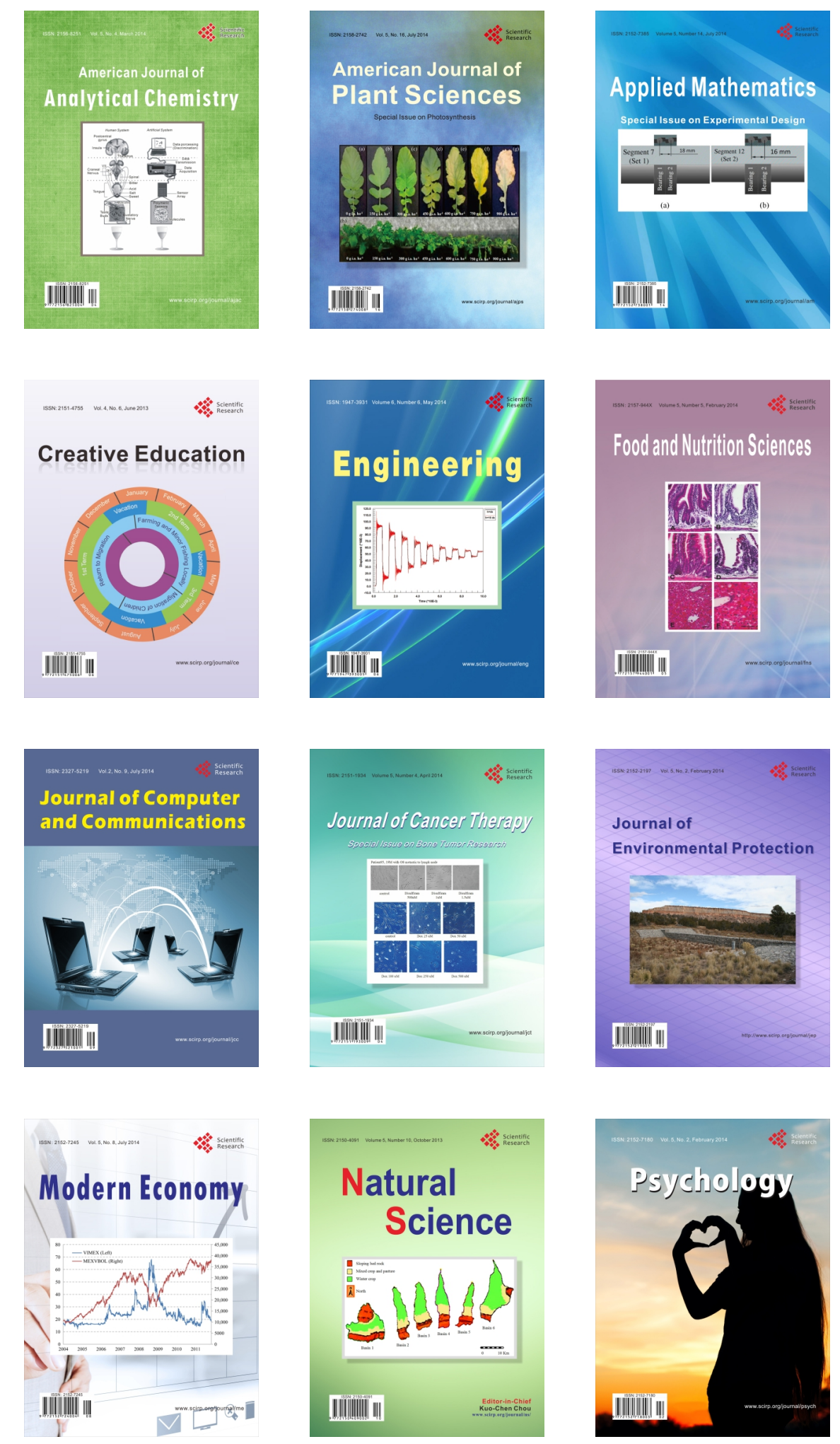